\title{
A Study on Local Universities' Innovation and Entrepreneurship Education
}

\author{
Peng Sun \\ Office of Educational Administration \\ Qilu Normal University \\ Jinan, China 250013
}

\begin{abstract}
At present, local college students' innovation and entrepreneurship education has many problems like student's sense of innovation is rather weak. The entrepreneurial education model is relatively old, the understanding of innovation and entrepreneurship education in society and schools is insufficient, the innovation and entrepreneurship education curriculum system needs to be improved, and the innovation and entrepreneurship practice base is too formal. Local colleges and universities should adopt hierarchical entrepreneurial education model to strengthen the cultivation and improvement of college students' innovative consciousness and innovative character, construct and perfect the entrepreneurship education and teaching system, let the undergraduates clear the goal of innovation and entrepreneurship education, and enhance the effectiveness of entrepreneurship education. We also should guarantee the incentive mechanism's continuity of entrepreneurship education, actively promote the cultivation of innovative and entrepreneurial talents in local colleges and universities, and serve local economic and social development.
\end{abstract}

Keywords-innovation and entrepreneurship education; undergraduate students; local school

\section{INTRODUCTION}

At present, it is significant for university students to conduct innovation and entrepreneurship education, especially in the provinces and cities affiliated colleges and universities (hereinafter referred to as local colleges and universities). It has an important significance for Industry Education Research and Practice for the Sustainable Development of Schools has an important significance.

College students' innovation and entrepreneurship is a very difficult and challenging social activity. Colleges and universities should cultivate the innovative qualities of undergraduates, and let them possess the basic skills and abilities of innovation and entrepreneurship. It is necessary to enrich the teaching content system and back-up support incubation measures for college students' innovation and entrepreneurship education. Developing a wide range of innovation and entrepreneurship education among college students reflects the new concept of talent cultivation in the contemporary society. This is not only to relieve employment pressure, but also to provide excellent talents for local economic development and social progress. The innovation and entrepreneurship education for undergraduates in local colleges and universities is still in its infancy and exploring stage. There is no mature model for reference and has not attracted widespread and extensive attention.

\section{THE STATUS QUO OF INNOVATION AND ENTREPRENEURSHIP EDUCATION FOR LOCAL COLLEGE STUDENTS}

At present, the awareness of innovation and entrepreneurship among local college students is generally weak. The form of entrepreneurial education is relatively simple, the mechanism for the sustainable development of university students is still not sound enough, the education model has not yet been fully formed, the subject system of innovation and entrepreneurship education is not perfect, and the innovation and entrepreneurship education of college students can only stay in the primary stage, failing to establish effective coordination. The win-win work pattern of college students, schools, and society has not formed, which leads to college students' consciousness of innovation and entrepreneurship and weaker innovation character.

Teachers are the successors and communicators of traditional culture and strive to maintain the tradition of teaching. The division-centered teacher-student relationship neglects the "object-oriented" relationship with the student body. Lack of educational significance and unequal relations is contrary to the current trend of social development. At present, some local college teachers are only the transfer of knowledge, ignoring the full range of attitudes, personality, methods and other aspects of the university students. They do not understand or tend to understand the psychological development and psychological needs of college students and cannot go inside their heart. Because they do not understand college students, they cannot guide and help college students in the true sense. Undergraduates do not feel the influence of teachers on learning attitude, learning methods and independent learning ability, so the dependence of college students on teachers will be reduced. As a result, the position of teachers in the minds of college students will also decline.

In the traditional concept of employment in China, the emphasis is on "smoothness" and "stability". In today's society, under the situation of increasingly severe employment situation, China's innovation and 
entrepreneurship is relatively scarce, and the consciousness of innovation and entrepreneurship of undergraduates also has many difficulties.

Local colleges and universities generally believe that the innovation and entrepreneurship education for college students is only the employment guiding work of college students. Most colleges and universities pay little attention to innovation and entrepreneurship education. Some colleges and universities only have one innovation and entrepreneurship education course for undergraduates. Some college students' innovation and entrepreneurship education only involves the second classroom, and the breadth and depth of innovation and entrepreneurship education for college students is obviously scarce. At present, many local colleges and universities have a certain degree of deviation in the teaching objectives and implementation process of innovation and entrepreneurship education for undergraduates. Teachers do not fully understand the innovation and entrepreneurship education of college students. Most of them believe that the primary task of college students is to learn professional knowledge. The task of teachers is to impart relevant professional knowledge.

The innovation and entrepreneurship practice base is the place to apply the theoretical knowledge learned in the classroom. The main platform used in practice is also one of the important ways to cultivate students' innovation and entrepreneurship and innovation and entrepreneurship. On the one hand, because the colleges and universities have different levels of recognition and emphasis on innovation and entrepreneurship education for college students, the construction of innovation and entrepreneurship practice bases for university students is also uneven. On the other hand, due to college students' innovation and entrepreneurship education funds and related support policies, etc. The restriction of factors has made some colleges and universities' innovation and entrepreneurship practice bases too formal, mainly in the following aspects: (1) The time for college students to practice is relatively short. In some colleges and universities, innovation and entrepreneurship education for undergraduates has not yet been included in formal personnel training programs. The timing of relevant innovation and entrepreneurship practices is not very standardized and time allocation is relatively little. (2) Some undergraduates have low expectations. Since college students spend more time in visiting than they do in practice, they easily make college students' fastidiou. There is no way to truly appreciate the actual innovation and entrepreneurship process. (3) The theory and practice are separated. The theoretical knowledge learned by the school is difficult to use in the practice of college students' innovation and entrepreneurship. The knowledge used in the innovation and entrepreneurship practice of college students is also hardly found in the textbooks. Therefore, the formalization of college students' innovation and entrepreneurship practice base has become formality, which restricting the improvement of the quality of college students' innovation and entrepreneurship education.

\section{COUNTERMEASURES FOR DEVELOPING COLLEGE STUDENTS' INNOVATION AND ENTREPRENEURSHIP EDUCATION IN LOCAL COLLEGES AND UNIVERSITIES}

\section{A. To Adopt Layered Entrepreneurial Education Model and to Strengthen College Students' Awareness of Innovation and Innovative Personality}

College students' innovation and entrepreneurship education needs to create a characteristic cultural context. The real realization must through an effective way to actively explore college students' innovation and entrepreneurship, and improve the corresponding institutional arrangements and linkages. The profound changes that Chinese manufacturing has created require innovative talents. Because of the constraints of social and economic structure, the number of university graduates can be absorbed by China' s GDP growth is far lower than that of developed countries. Therefore, China' s innovative entrepreneurship education, innovation and entrepreneurship practices must be strengthened. Colleges and universities should actively integrate various resources within the school to provide college students with innovative and entrepreneurial education in a variety forms and rich content. Organize the third classroom to use economic and technological development zones, high-tech development zones, industrial parks and university science and technology parks, building innovative and entrepreneurial incubation bases for the innovation and entrepreneurship practice of college students, and providing greater support in terms of policies, funds, projects, etc.

For some higher vocational colleges, which belong to professional universities, the main training is vocational talents. Therefore, carrying out innovation and entrepreneurship education for undergraduates in higher vocational colleges must adopt different levels of teaching with the different characteristics and needs of different students to meet the special needs of higher vocational students. Higher vocational colleges must first determine the guiding ideology of running a school according to their own level, and formulate the basic goals of entrepreneurship education. All along, the society generally believes that vocational colleges cultivate traditional employment talents. Most of these graduates lack entrepreneurial awareness and entrepreneurial abilities, which results in higher vocational graduates who can only work in their own jobs and have low entrepreneurial success cases. In view of the poor entrepreneurial awareness and entrepreneurial enthusiasm of higher vocational students, higher vocational colleges should start from the concept of entrepreneurship education and improve the educational model, establish a sound organizational structure, build a practical platform for entrepreneurship education, and infiltrate entrepreneurship education into personnel training. Throughout the entire process, they develop comprehensive entrepreneurial skills such as entrepreneurial quality, entrepreneurial knowledge, and entrepreneurial physiology. In the process of entrepreneurship education, emphasis should be placed on professionalism and professionalism, focusing on cultivating 
the pioneering spirit and comprehensive entrepreneurial ability of higher vocational students, etc.

\section{B. To Construct and Improve College Students' Innovation and Entrepreneurship Education and Teaching System, Clarify the Employment Goals of Innovation and Entrepreneurship, and Enhance the Effectiveness of Innovation and Entrepreneurship Education for College Students}

The entrepreneurship education curriculum system is the central link in the implementation of entrepreneurship education, through which the concept of educational theory can be transformed to educational practice. To set up an entrepreneurial education curriculum system, it must be ensured to be reasonable and effective. Entrepreneurship courses take two modes of operation: (1) Embedded. The entrepreneurial education operation process should be incorporated into the overall framework of the activity curriculum, and various forms of entrepreneurship education activities should be carried out in conjunction with various social activities within and outside the classroom. (2) Penetration. The contents of entrepreneurship education should be incorporated into the current subject curriculum system, and the content of entrepreneurship education should be infiltrated into the corresponding classroom teaching according to the specific characteristics of different disciplines. In the implementation of the entrepreneurial curriculum, following the principle of gradual and orderly progress, it can be divided into three stages: the basic stage is for cultivating college students' entrepreneurial awareness and entrepreneurship; the intermediate stage is a practical course for cultivating college students' entrepreneurial skills; and the advanced stage is for cultivating the actual entrepreneurial ability of college students.

High quality entrepreneurial practice base is the main link in the implementation of entrepreneurship education. Currently, many colleges and universities' existing practice bases for innovation and entrepreneurship in colleges and universities have problems such as having few mobile phones, short practice time, and disconnecting theories from practice. Therefore, colleges and universities should actively build a professional practice base. This base should incorporate two modes of incubation and off-campus demonstration on campus so that undergraduates can observe both the internship and the actual entrepreneurial process. At the same time, they master the knowledge of entrepreneurial ideas. Institutions of higher learning should establish oncampus entrepreneurship bases and off-campus demonstration bases. The university' $\mathrm{s}$ entrepreneurial practice bases mainly use the platforms created by the government and social resources. Targeting students at school, the entrepreneurial project team is the basic organizational form and is equipped with entrepreneurial instructors. Assisting university students in solving some difficulties encountered in the practice of entrepreneurship. Some strong vocational colleges can take their own advantages to establish some entrepreneurial entities, such as entrepreneurship incubator bases, etc., to provide college students with the necessary seminar venues for entrepreneurship, colleges and universities to provide financial support and consulting services, and actively guide college students to conduct their own business. Encourage the students to engage in entrepreneurial activities such as business activities, technological achievements, and technical services.

\section{To Improve the System Guarantee Incentive Mechanism, to Ensure the Extension of College Students' Innovation and Entrepreneurship Education Continuity}

The management of local colleges and universities should strengthen the emphasis on entrepreneurship education and improve the management level of entrepreneurship education. Colleges and Universities should provide policy support and form a complete management system to make education for undergraduates' innovation and entrepreneurship smoothly. On the one hand, aiming at the problem of underdeveloped infrastructure and insufficient teachers in innovation and entrepreneurship education for undergraduates, we must increase input and vigorously improve the software and hardware construction of college students' innovation and entrepreneurship education. In the construction of innovation and entrepreneurship education system for college students, we should adopt flexible and varied policies and measures. For example, we can adopt a flexible credit system for college students who are in the entrepreneurial stage, allowing them to complete their studies in stages; For those with strong creativity For college students, the school can allow them to leave school and enter the social entrepreneurship. The school retains its student status to solve their worries. On the other hand, colleges and universities should allocate outstanding teachers for innovation and entrepreneurship education for college students, support the entrepreneurial research work carried out by teachers, and constantly improve the knowledge structure of teachers' entrepreneurship. In addition, it is also possible to introduce social teachers to enrich and strengthen the teaching staff of college students' innovation and entrepreneurship education.

Universities should create a strong atmosphere of innovation and entrepreneurship for college students in the teaching process.

Three step classrooms should be set up. In accordance with the teaching plan, classrooms should be taught in the classroom as the first classroom, after class time as the second classroom, and social practice as the third classroom, so that various activities of the school become effective carriers for the innovation and entrepreneurship education of college students, and then guide various organizations pay attention to the theme of innovation and entrepreneurship education for college students to carry out activities, and set an example of college students' innovation and entrepreneurship, encourage colleges and universities to shift their focus from employment to guide college students to take the initiative in innovation and entrepreneurship, to facilitate China's college education system innovation and education reform. In recent years, due to the expansion of enrollment in colleges and universities and the increase in the number of graduates, college students are facing a great 
deal of employment pressure. Therefore, college students' innovation and entrepreneurship is one of the most effective and positive ways for university graduates to get employed. It is an important way for them to participate in economic and social development. Moreover, many college students come from rural areas. If they can use their studies to return home, they can not only solve their problems. With regard to its own employment issues, it can create more jobs and achieve a multiplier effect of employment.

\section{CONCLUSION}

College students' innovation and entrepreneurship is a very difficult and challenging social activity. At present, college students' consciousness of innovation and entrepreneurship character are relatively weak, and the model of college students' innovation and entrepreneurship education is rather obsolete. Society and schools lack understanding of innovation and entrepreneurship education for college students, and the course system for undergraduate innovation and entrepreneurship education needs to be improved. The practice base for college students' innovation and entrepreneurship is too formal. It is suggested that a stratified entrepreneurial education model be adopted to strengthen the cultivation and improvement of college students' innovative consciousness and innovative character. We should construct and improve the college students' innovation and entrepreneurship education and teaching curriculum system, so that the college students can clarify the employment goals of innovation and entrepreneurship, and enhance the effectiveness of innovation and entrepreneurship education for college students. We should also improve the institutional guarantee and incentive mechanism to ensure the continuity of innovation and entrepreneurship education for college students.

\section{REFERENCES}

[1] Chen Shuping, Thoughts on Developing the Theory and Practice of Entrepreneurial Education in Colleges and Universities [J]. Guang Ming Daily, 2000,5,10

[2] Ji Shujun. Entrepreneurship education in vocational colleges from the perspective of entrepreneurship and enriching people $[\mathrm{J}]$. Chinese Ault Education, 2009

[3] Lu Ming, Research Progress on University Students' Employment Ability [J]. Modern Education, 2008(7):102-105

[4] Niu Changsong. Research on Entrepreneurship Education in British Universities [M]. Shanghai: Xuelin Press, 2009

[5] Shi Gendong, Create a new talent training model [J]. Shanghai, Shanghai International Studies University, 2004

[6] Zhu Xinchegn, On the Cultivation of College Students' Employment Ability [J].Xi'an Institute of Foreign Languages. 2003 (4): 27-30 